\title{
Proteome Analysis of PC12 Cells Reveals Alterations in Translation Regulation and Actin Signaling Induced by Clozapine
}

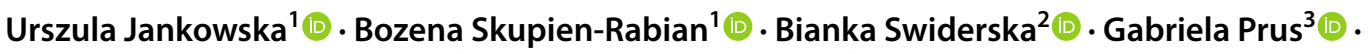 \\ Marta Dziedzicka-Wasylewska ${ }^{3}$ (D) Sylwia Kedracka-Krok ${ }^{3}$ (i)
}

Received: 17 December 2020 / Revised: 19 April 2021 / Accepted: 12 May 2021 / Published online: 23 May 2021

(c) The Author(s) 2021

\begin{abstract}
Although antipsychotics are routinely used in the treatment of schizophrenia for the last decades, their precise mechanism of action is still unclear. In this study, we investigated changes in the PC12 cells' proteome under the influence of clozapine, risperidone, and haloperidol to identify protein pathways regulated by antipsychotics. Analysis of the protein profiles in two time points: after 12 and $24 \mathrm{~h}$ of incubation with drugs revealed significant alterations in 510 proteins. Further canonical pathway analysis revealed an inhibition of ciliary trophic factor signaling after treatment with haloperidol and showed a decrease in acute phase response signaling in the risperidone group. Interestingly, all tested drugs have caused changes in PC12 proteome which correspond to inhibition of cytokines: tumor necrosis factor (TNF) and transforming growth factor beta 1 (TGF- $\beta 1$ ). We also found that the 12-h incubation with clozapine caused up-regulation of protein kinase A signaling and translation machinery. After $24 \mathrm{~h}$ of treatment with clozapine, the inhibition of the actin cytoskeleton signaling and Rho proteins signaling was revealed. The obtained results suggest that the mammalian target of rapamycin complex 1 (mTORC1) and 2 (mTORC2) play a central role in the signal transduction of clozapine.
\end{abstract}

Keywords Actin signaling $\cdot$ Clozapine $\cdot$ mTOR $\cdot$ Antipsychotic drugs $\cdot$ Proteome $\cdot$ Translation

$\begin{array}{ll}\text { Abbreviations } \\ \text { AGC } & \text { Automatic gain control } \\ \text { Akt } & \text { Protein kinase B } \\ \text { AMP } & \text { Adenosine monophosphate } \\ \text { AMPK } & \text { AMP-activated protein kinase } \\ \text { CNTF } & \text { Ciliary neurotrophic factor } \\ \text { IL1RN } & \text { Interleukin-1 receptor antagonist protein } \\ \text { IPA } & \text { Ingenuity Pathway Analysis } \\ \text { IS } & \text { Internal standard } \\ \text { MAP2K2 } & \text { MAP kinase kinase 2 } \\ \text { mTOR } & \text { Mammalian target of rapamycin }\end{array}$

Urszula Jankowska

urszula.jankowska@uj.edu.pl

1 Proteomics and Mass Spectrometry Core Facility, Malopolska Centre of Biotechnology, Jagiellonian University, Gronostajowa 7a str, 30-387 Krakow, Poland

2 Mass Spectrometry Laboratory, Institute of Biochemistry and Biophysics Polish Academy of Sciences, Pawinskiego 5a, Warsaw, Poland

3 Department of Physical Biochemistry, Faculty of Biochemistry, Biophysics and Biotechnology, Jagiellonian University, Gronostajowa 7, Krakow, Poland

$\begin{array}{ll}\text { mTORC1 } & \text { MTOR complex 1 } \\ \text { mTORC2 } & \text { MTOR complex 2 } \\ \text { NCE } & \text { Normalized collision energy } \\ \text { NFAT } & \text { Nuclear factor of activated T-cells } \\ \text { NT5C2 } & \text { Cytosolic purine 5'-nucleotidase } \\ \text { MMP14 } & \text { Matrix metalloproteinase-14 } \\ \text { PIK3C3 } & \text { PI3-kinase type 3 } \\ \text { PKA } & \text { Protein kinase A } \\ \text { PTPN11 } & \text { Tyrosine-protein phosphatase non-receptor } \\ & \text { type 11 } \\ \text { SASP } & \text { Senescence-associated secretory phenotype } \\ \text { SERPINE1 } & \text { Plasminogen activator inhibitor 1 } \\ \text { SHC1 } & \text { SHC-transforming protein 1 } \\ \text { TGF- } \beta 1 & \text { Transforming growth factor beta 1 } \\ \text { TNF } & \text { Tumor necrosis factor }\end{array}$

\section{Introduction}

Antipsychotics are commonly used for treating schizophrenia, bipolar disorder, and other psychotic diseases [2]. Treatment of schizophrenia is considered one of the greatest challenges of modern clinical psychiatry, as around $30 \%$ of 
patients do not respond to pharmacotherapy and it is associated with the risk of serious side effects [3].

Although the receptor profile of antipsychotics is relatively well understood, the precise mechanism of these agent's action remains unclear. Different therapeutic effects of drugs are probably related to their diverse affinity for individual receptors, but another explanation is based on the observation that the conformational changes of the receptor may be different depending on the ligand, leading to the activation of different signal transduction cascades [4]. All antipsychotics block the dopamine D2 receptor and increase the pathway of cyclic AMP/protein kinase A (PKA) [2]. The other pathways relevant to antipsychotics pharmacology are: the protein kinase B (Akt)/glycogen synthase kinase pathway, the mitogen-activated protein kinase cascade, and the $\beta$-arrestin-2-dependent signaling [5, 6]. The pathways interplay at various levels of signal transduction, i.e., secondary messengers, signaling proteins/kinases/phosphatases, and transcription factors, which generates a complex system of mutual dependencies [5].

Clozapine has a multireceptor binding profile, including affinity for serotonergic, dopaminergic, and muscarinic receptors [7]. It is the first atypical drug, introduced to clinics in the 1970s, and remains the most effective antipsychotic drug to the present day [8]. Clozapine demonstrates effectiveness not only for treating the positive, but also to a certain degree negative and cognitive symptoms (improved verbal fluency) of schizophrenia with a greatly reduced tendency to induce extrapyramidal side effects and tardive dyskinesia [9]. However, due to the risk of serious side effects such as potentially life-threatening agranulocytosis, metabolic disorders, and myocarditis, clozapine is prescribed rarely, mainly in treatment-resistant schizophrenia. Its introduction to the therapy was the last crucial innovation in psychopharmacology of schizophrenia [10]. The lack of breakthrough since then indicates that novel therapeutics should be aimed at cellular and molecular targets, rather than just the dopamine or serotonin receptors [8].

Therefore, this study aimed to identify protein pathways regulated by antipsychotics with different mode of action (haloperidol, risperidone, and clozapine) using quantitative proteomics methods. Haloperidol is a representative of older, typical antipsychotics and exhibits high affinity dopamine D2 receptor antagonism. Risperidone is considered atypical, nonetheless, it has intermediate properties between both groups of antipsychotics.

In this study, the effect of antipsychotics was examined on cells derived from a pheochromocytoma of rat adrenal medulla (PC12 cells). The PC12 cell line is one of the most valuable mammalian cell model commonly used to study nervous system disorders and the mechanisms of drug action $[11,12]$. The PC12 cells respond to the nerve growth factor and are able to synthetize and store neurotransmitters [13]. The choice of PC12 cells was also dictated by the presence of antipsychotic receptors: D1, D2, D4, 5HT2A, 5HT3, M1, M4, M5 [14-18].

Therefore, in the presented study, we investigated the alterations in the protein profile of $\mathrm{PC} 12$ cells induced by clozapine, risperidone, and haloperidol to provide insights into further stages of signal transmission for antipsychotics. Distinguishing the crucial pathways underlying antipsychotics' activity may contribute to developing novel medications with greater efficacy and improved tolerability.

Quantitative proteomics was carried out using two approaches: iTRAQ-based and 2D-DIGE. The methods complement each other, allowing to get a broader picture of PC12 cells' proteome. To observe the changes at various stages of signal transduction, the proteomic analysis was performed at two time points (12 and $24 \mathrm{~h}$ of incubation). The Ingenuity Pathway Analysis (IPA) was used to identify protein interaction networks and signaling pathways activated or inhibited under the influence of drugs.

\section{Materials and Methods}

\section{Cell Culture and Protein Sample Preparation}

PC12 cells (American Type Culture Collection) were grown in F12K medium (Sigma-Aldrich) supplemented with 15\% horse serum and 2.5\% FBS (Sigma-Aldrich). Upon reaching $~ 80 \%$ confluency, the media were changed to media containing one of the drugs: clozapine $(10 \mu \mathrm{M})$, haloperidol $(3 \mu \mathrm{M})$, risperidone $(3 \mu \mathrm{M})$ or vehicle solution $(0.33 \%$ ethanol, Sigma-Aldrich). The concentrations of haloperidol and risperidone were according to works of Kashem et al. and Ahmed et al. [19, 20]. The clozapine concentration was based on works of Tejedor-Real et al. and Weintraub et al. $[21,22]$. Tejedor-Real et al. showed that the reduced level of tyrosine hydroxylase observed in the rat brain after clozapine administration was obtained in PC12 cells already at the drug concentration of $10 \mu \mathrm{M}$ [21]. After 12 or $24 \mathrm{~h}$ of incubation, the cells were washed twice with $5 \mathrm{mM}$ magnesium acetate in $10 \mathrm{mM}$ Tris, $\mathrm{pH} 8.0$ and lysed directly on a culture dish in ice-cold lysis buffer (7 M urea, $2 \mathrm{M}$ thiourea, $4 \%$ CHAPS, $30 \mathrm{mM}$ Tris $\mathrm{pH}$ 8.5). The extracts were sonicated at $320 \mathrm{~W}, 20 \mathrm{kHz}, 30 \mathrm{~s} / 30 \mathrm{~s}$ on/off for $15 \mathrm{~min}$ in a Bioruptor UCD-200 (Diagenode), centrifuged at 20,000 $\mathrm{g}$ for $15 \mathrm{~min}$ at $15{ }^{\circ} \mathrm{C}$ and supernatants were collected. The experiment was performed in six replicates, between passages 6 and 12. The protein concentration was determined using the Bradford assay [23]. To facilitate normalization and quantification of the data, an internal standard (IS) was prepared by combining $75 \mu \mathrm{g}$ of protein mixture from each sample (48 samples). 


\section{ITRAQ}

\section{Protein Digestion, iTRAQ Labeling, and Peptide Fractionation by IEF}

For the 8-plex iTRAQ labeling (Applied Biosystems), $25 \mu \mathrm{g}$ of protein mixtures from two biological replicates were pooled. Protein digestion and peptide labeling was performed on spin columns with a 30-kDa membrane cutoff (Vivacon500, Sartorius Stedim) according to the iFASP procedure (isobaric mass tagging with filter-aided sample preparation) [24] with some modifications. A labeling scheme is shown in Supplementary file 1. Salts and excess reagents were removed from the combined filtrates by solid phase extraction on C18 Extraction Disk Cartridges (Empore $7 \mathrm{~mm}$ dia. $/ 3 \mathrm{ml}$ vol., Sigma). To minimize the precursor coisolation occurrence, peptides were separated by IEF into 34 fractions on $24 \mathrm{~cm}$ linear pH 3-10 Immobiline DryStrips (GE Healthcare). Peptides were extracted from the gels, vacuum-dried, and purified on C18 StageTips [25]. A detailed procedure is presented in Supplementary file 1.

\section{LC-MS/MS of Labeled Peptides}

Each fraction was analyzed in two technical replicates by LC-MS/MS with an UltiMate 3000RSLCnano System (Thermo Scientific) coupled via a Digital PicoView 550 nanospray source (New Objective) to a Q-Exactive (Thermo Scientific) mass spectrometer. Peptides were injected into a precolumn (AcclaimPepMap100 C18, $2 \mathrm{~cm} \times 75 \mu \mathrm{m}, 3 \mu \mathrm{m}$, $100 \AA$ ) using $4 \%$ ACN with $0.05 \%$ TFA as the mobile phase and further separated on an analytical column (AcclaimPepMapRLSC C18, $50 \mathrm{~cm} \times 75 \mu \mathrm{m}, 2 \mu \mathrm{m}, 100 \AA$ ) with a 4-44\% ACN gradient in the presence of $0.05 \%$ formic acid for $120 \mathrm{~min}$ at a flow rate of $300 \mathrm{nl} / \mathrm{min}$. The Q-Exactive was operated in a data-dependent mode using a top ten method at $33 \%$ of normalized collision energy (NCE) and $30 \mathrm{~s}$ of dynamic exclusion. Full scan MS spectra were acquired from 350 to $1800 \mathrm{~m} / \mathrm{z}$ with a resolution of 70,000 at m/z 200 and using an automatic gain control (AGC) target of 1e6. The MS/MS spectra were acquired with a resolution of 17,500 at $\mathrm{m} / \mathrm{z} 200$ with an AGC target of 5e4. The maximum ion accumulation time for the full MS and MS/MS scans was $100 \mathrm{~ms}$. The lock mass option was enabled for survey scans to improve mass accuracy. The MS proteomics data have been deposited to the ProteomeXchange Consortium via the PRIDE [1] partner repository with the dataset identifier PXD014422.

\section{Data Analysis}

The Proteome Discoverer platform (v. 1.4, Thermo Scientific) was used for identification and preliminary quantification of proteins. The data obtained from both technical replicates were searched together against the Swiss Prot_201506 database with taxonomic restriction to Rodentia (26 322 sequences) using an in-house Mascot server (v. 2.5.0, Matrix Science) with the following parameters: digestion by trypsin with a maximum of two missed cleavages; iTRAQ 8-plex (K, N-terminus) and carbamidomethylation (C) as fixed modification; oxidation (M) and deamidation (NQ) as variable modifications. Mass tolerance for the precursor and fragment ions was set to $10 \mathrm{ppm}$ and $20 \mathrm{mmu}$, respectively. The FDR for peptides was calculated by a target-decoy approach and was set to $1 \%$. Percolator algorithm was used to assess the reliability of protein identification. During the quantitative analysis, a "quan value correction" was used, related to the incomplete purity of the individual markers. Quantitative information was only obtained from unique peptides with the co-isolation below $50 \%$. A quantitative analysis combining all results was carried out in the Scaffold Q+ (version 4.4.7, Proteome Software Inc.). Threshold of $95 \%$ probability was used for peptide and protein identification. Protein probabilities were assigned by the Protein Prophet algorithm [26]. In addition, protein identification required at least two identified peptides. Proteins that shared the assigned peptides with other entries and could not be differentiated were grouped to satisfy the principles of parsimony. Channels were corrected in all samples according to the algorithm described in i-Tracker [27]. Acquired intensities in the experiment were globally normalized across all acquisition runs. Individual quantitative samples were normalized within each acquisition run. Intensities for each peptide identification were normalized within the assigned protein. The reference channels from IS (113) were normalized to produce a 1: onefold change. All normalization calculations were performed using averages to multiplicatively normalize data.

\section{DIGE}

\section{Cyanine Dye Labeling and Protein Separation by 2DE}

Six replicates from each group were analyzed by DIGE. Lysates containing $800 \mu \mathrm{g}$ of protein were purified by methanol/chloroform precipitation according to the previous protocol [28]. Pellets were dissolved in the lysis buffer. Protein concentrations were measured by the Bradford assay and adjusted to $4.5 \mathrm{mg} / \mathrm{ml}$. Labeling of the proteins and separation by 2DE was executed as described in our earlier work [29]. Briefly, $33 \mu \mathrm{g}$ of protein from each sample was labeled with 110 pmol of Cy3 or Cy5 and the IS was labeled with Cy2. Samples were combined according to Table S1 in Supplementary file 1 and loaded onto $24 \mathrm{~cm}$ nonlinear pH 3-10 Immobiline DryStrips (GE Healthcare). IEF was performed on a PROTEAN® ${ }^{1} 12^{\text {TM }}$ IEF System 
for a total of $78000 \mathrm{Vhr}$. SDS-PAGE was carried out using an Ettan DALTsix Large Vertical System (GE Healthcare). Fluorescent images of the DIGE gels were obtained using the Typhoon Trio + Imager (GE Healthcare) at a resolution of $100 \mathrm{dpc}$. Next, the gels were stained with a lab-made ruthenium II tris-(bathophenanthroline disulfonate) and scanned again [30].

\section{Gel Image Analysis}

The evaluation of the DIGE gel patterns was performed using the difference in gel analysis mode and the biological variation analysis mode of DeCyder software v7.2 (GE Healthcare) as described previously [29]. Detection algorithm 6.0 was used with an estimated number of spots set to 10000 . In order to exclude artifacts, spots which volume value was less than 30000 were rejected. Correct matching of the spots across the gels was manually checked.

\section{Protein Identification from Gel Spots by LC-MS/MS}

The selected spots were cut using an automatic Ettan SpotPicker (GE Healthcare) and in gel digested with trypsin as reported previously [31]. Protein identification was performed on the LC-MS system featured above (iTRAQ section) with the following modifications. Peptides were loaded onto the precolumn using $2 \%$ ACN with $0.05 \%$ TFA and separated with a $30-$ min gradient $2-40 \%$ ACN in $0.05 \%$ formic acid on a $15 \mathrm{~cm}$ analytical column (AcclaimPepMapRLSC, $15 \mathrm{~cm} \times 75 \mu \mathrm{m}, \mathrm{C} 18,2 \mu \mathrm{m}, 100 \AA$ ). The top six method was used with NCE set to 27 . Full scan MS spectra were acquired with a resolution of 70,000 at $\mathrm{m} / \mathrm{z}$ 200 with an AGC target of $1 \mathrm{e} 6$. The MS/MS spectra were acquired with a resolution of 35,000 at $\mathrm{m} / \mathrm{z} 200$ with an AGC target of 5e5. The maximum ion accumulation time for the full MS and MS/MS scans was $120 \mathrm{~ms}$. The RAW MS files were processed by the Proteome Discoverer platform and searched against the Swiss Prot_201505 database restricted to Rodentia taxonomy (26,248 sequences) with the following parameters: digestion by trypsin with maximum one missed cleavage; carbamidomethylation (C) as fixed modification; oxidation (M) and phosphorylation (STY) as variable modifications; peptide mass tolerance $\pm 10 \mathrm{ppm}$ and fragment mass tolerance $\pm 20 \mathrm{mmu}$. Only proteins identified with at least two peptides and with a Mascot score value over 90 were accepted. Each identification was confirmed from at least two gels. Only unambiguous identifications were accepted.

\section{Ingenuity Pathway Analysis (IPA)}

The differential proteins identified with iTRAQ and DIGE methods were combined and imported into the IPA platform
(Ingenuity® Systems; http://www.ingenuity.com). The computational algorithms of the software use annotation of the biological literature to identify biological functions, protein interaction networks, and signaling pathways regulated in the same way (activated or inhibited). The analysis of upstream regulators includes determining proteins (or small molecule compounds, miRNAs), which can be responsible for observed changes in the proteome. The great advantage of the program is considering not only the type of the protein, but also the direction of the observed alterations.

\section{Statistical Analysis}

Statistical significance of the differentially expressed proteins was assessed using the Student's t-test. Calculations were performed with Scaffold Q+ and with Biological Variation Analysis module of Decyder 7.0 for ITRAQ and DIGE experiments, respectively. Proteins whose relative expression was changed $>1.17$-fold across groups at the $95 \%$ confidence level were considered significant ( $p$ value $<0.05$ and $\mathrm{FC}>1.17$ or $\mathrm{FC}<-1.17)$. This assumed that even slight variations in the levels of multiple proteins can result in pathway alterations. Overlap of observed and predicted regulated protein sets in the IPA was calculated using the Fisher's exact test (significance threshold: $p$ value $<0.05$ ). Activation z-score was computed to predict regulation patterns as inhibition (z-score $\leq-2$ ) or activation (z-score $\geq 2$ ) [32].

\section{Results and Discussion}

In this study, we aimed to explore alterations in the protein profile of PC12 cells after incubation with antipsychotic drugs: clozapine, risperidone, and haloperidol for 12 and $24 \mathrm{~h}$. Six biological replicates of the control and treated samples were analyzed with two high-throughput proteomics approaches: iTRAQ and DIGE. Proteins from cell lysates were digested, labelled with 8-plex iTRAQ tags, and analyzed by the Orbitrap Q-Exactive mass spectrometer. As a result, on average $4523 \pm 866$ proteins were identified. Quantitative analysis was performed on 3117 proteins with at least two unique peptides assigned with the use of Scaffold Q+ software. Signal intensities of peptides in individual samples were normalized (Supplementary file 1, Fig. S1). There were 510 differential proteins found (Supplementary file 2). With the DIGE method 48 samples (and IS) were separated on 24 gels based on their size and pI values. On each gel, on average, $5240 \pm 550$ spots were detected and about $70 \%$ of them were matched and quantified. For each spot, the ratio of the normalized mean spot volume relative to the control was calculated. We found significant alterations in 78 spots. Proteins were unambiguously identified in 59 spots (Supplementary file 2), the position of which 

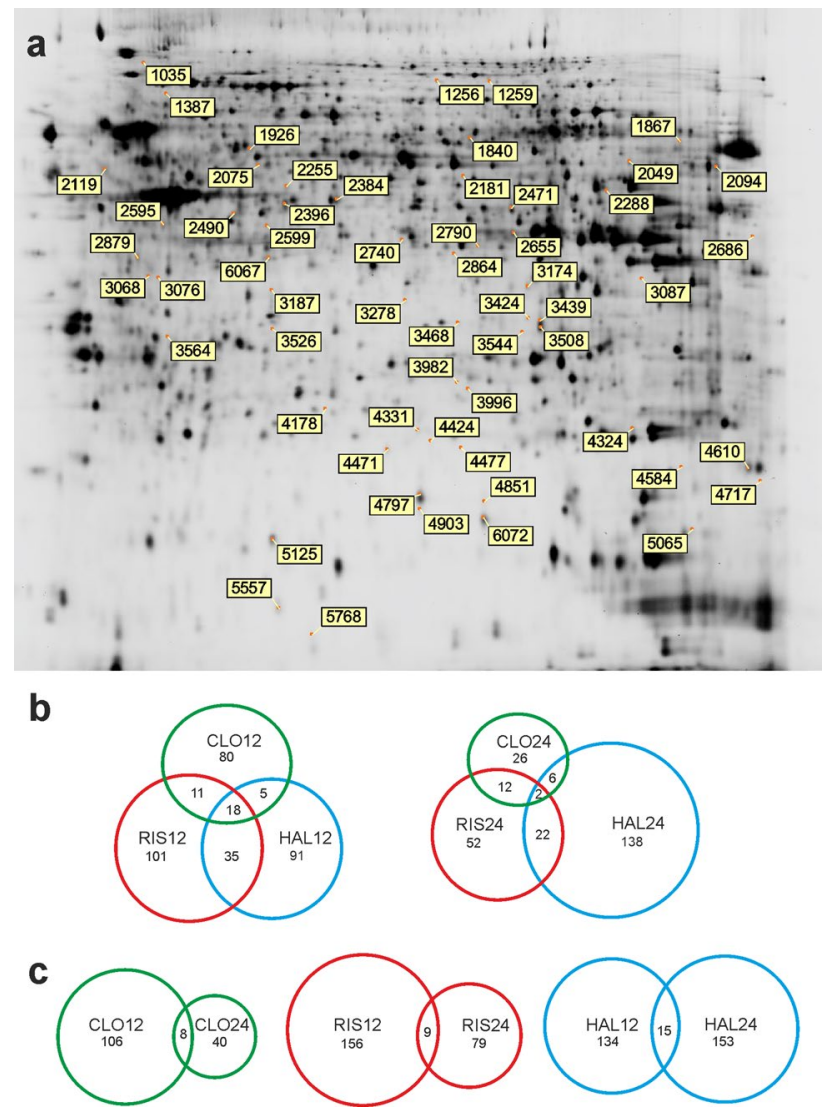

Fig. 1 Representative DIGE gel image of internal standard from PC12 cells with marked differential proteins after treatment with studied antipsychotic drugs (A). Venn diagrams demonstrating the overlap between differential proteins found after treatment with clozapine (CLO), risperidone (RIS), haloperidol (HAL) (B), regarding the time of incubation $(12 \mathrm{~h} / 24 \mathrm{~h})(\mathbf{C})$

is shown on a representative electrophoretic gel image (Fig. 1a). The differential proteins identified by the iTRAQ method were distinct from those obtained by the DIGE method. Only two proteins, cofilin-1 and destrin, were found to be differentially expressed by both methods. In the case of cofilin-1, the upregulation after clozapine treatment was detected using the iTRAQ approach, while DIGE showed downregulation of this protein in response to risperidone and haloperidol. For destrin, the iTRAQ analysis showed the higher abundance of this protein after incubation with clozapine and risperidone. On the other hand, the lower level of destrin was revealed for haloperidol as well as risperidone using DIGE. The discrepancy in the direction of change for risperidone may be concerning, however, results from the gel-based approach may not refer to the outcome of the iTRAQ analysis as two methods quantify different pools of proteins. The peptide-level quantification used in iTRAQ provides information about the protein abundance, but without distinction between the forms of protein, while in DIGE protocol protein species (i.e. isoforms, modified forms) are separated and quantified before the enzyme digestion [33]. Thus, a given protein can be present in several spots, which was also the case in our experiment (see examples in a table in Supplementary file 2). The complementary nature of DIGE and iTRAQ methods has also been shown in other proteomics studies [34-36].

\section{Shared Changes in PC12 Proteome Induced by Clozapine, Risperidone, and Haloperidol}

Venn diagram analysis indicated that very few proteins demonstrated overlapping changes induced by all studied antipsychotics (Fig. 1b, c). Only 23 proteins with altered expression were common to clozapine, risperidone, and haloperidol (excluding the incubation time factor). Shared differential proteins with a brief description of their functions were presented in Table 1. Interestingly, most of shared alterations were identified after $12 \mathrm{~h}$ of drug incubation, suggesting that drugs generally share only initial step in signal transduction pathways. A common observation among groups was downregulation of plasminogen activator inhibitor 1 (SERPINE1), which is a part of the senescenceassociated secretory phenotype (SASP) and is involved in controlling inflammation, which is significant risk factor of schizophrenia [37, 38]. Enhanced SERPINE1 levels are associated with many pathophysiological processes including metabolic disturbances, insulin resistance syndrome, chronic stress and development of cardiovascular disease [39]. Next common alteration after $12 \mathrm{~h}$ of incubation with drugs was downregulation of matrix metalloproteinase-14 (MMP14), which together with SERPINE1 controls extracellular matrix proteolysis [40]. Metalloproteinases play an important role in schizophrenia and other neuropsychiatric disorders probable by abnormal synaptic plasticity and functional reorganization of excitatory synapses that are located on dendritic spines [41]. Moreover, metalloproteinases influence learning and memory processes and are linked to progression of neuroinflammatory disorders [42].

For a broader interpretation of the results, a functional analysis on several levels was performed in IPA: pathway enrichment, upstream regulators, functional networks. Detailed results are presented in Supplementary file 3. The canonical pathway analysis in IPA revealed eight signaling pathways with statistically significant alteration in at least one study group, which are presented in Table 2 . The upstream regulator analysis indicated that changes in PC12 proteome under the influence of all tested antipsychotics correspond to molecular changes typical for inhibition of cytokines: TNF and TGF- $\beta 1$ (Fig. $2 \mathrm{ab}$ ). Interestingly, this conclusion was made on the basis of mostly different proteins in each group, what suggests that antipsychotics affects proteins engaged in inflammatory process, but in a different way. Increased TNF- $\alpha$ and other inflammatory 
Table 1 Fold change of differential proteins detected in PC12 cells shared between drugs: clozapine (CLO), risperidone (RIS), and haloperidol (HAL) revealed by iTRAQ or DIGE methods

\begin{tabular}{|c|c|c|c|c|c|c|c|c|}
\hline \multicolumn{6}{|c|}{ Fold Change } & \multirow{2}{*}{ Gene Name } & \multirow{2}{*}{ Protein name } & \multirow{2}{*}{ Function / Biological process } \\
\hline CLO12 & $\mathrm{CLO} 24$ & RIS12 & RIS24 & HAL12 & HAL24 & & & \\
\hline & -1.19 & -1.26 & & -1.20 & & Dst & Dystonin & $\begin{array}{l}\text { actin and microtubule binding, cytoskeletal linker protein, regulation of stability of } \\
\text { the microtubule network of sensory neurons to allow axonal transp ort }\end{array}$ \\
\hline & & -1.44 & & -1.45 & & \multirow{3}{*}{ CFL1 } & \multirow{3}{*}{ Cofilin-1 } & \multirow{3}{*}{$\begin{array}{l}\text { F-actin depolymerizing activity, } \\
\text { involved in mitosis, cytokinesis, cytoskeletal organization }\end{array}$} \\
\hline & & -1.25 & & -1.50 & & & & \\
\hline 1.21 & & & & & & & & \\
\hline & & -1.42 & & & -1.41 & \multirow{3}{*}{ Dstn } & \multirow{3}{*}{ Destrin } & \multirow{3}{*}{ F-actin depolymerizing activity; binds to actin monomers, cell motility } \\
\hline & & & & -1.45 & & & & \\
\hline 1.18 & & 1.18 & & & & & & \\
\hline \multirow[t]{4}{*}{-1.25} & & -1.22 & & -1.18 & & HDAC6 & Histone deacetylase 6 & $\begin{array}{l}\text { deacetylation of lysine residues on the } \mathrm{N} \text {-terminal part of the core histones }(\mathrm{H} 2 \mathrm{~A} \text {, } \\
\mathrm{H} 2 \mathrm{~B}, \mathrm{H} 3 \text { and } \mathrm{H} 4) \text {, transcriptional regulation, cell cycle progression, and } \\
\text { developmental events, binding to actin, microtubules and dynein }\end{array}$ \\
\hline & & & & -1.31 & 1.17 & \multirow{4}{*}{ MYH9 } & \multirow{4}{*}{ Myosin-9 } & \multirow{4}{*}{$\begin{array}{l}\text { microfilament motor activ ity, actin cytoskeleton reorganization, } \\
\text { establishment of meiotic spindle localization }\end{array}$} \\
\hline & & & -1.34 & & -1.28 & & & \\
\hline & & & & -1.23 & -1.23 & & & \\
\hline-1.19 & & -1.28 & & -1.26 & & & & \\
\hline-1.19 & & -1.2 & & -1.25 & & CCDC6 & $\begin{array}{l}\text { Coiled-coil domain-containing } \\
\text { protein } 6\end{array}$ & structural constituent of cytoskeleton \\
\hline-1.25 & & -1.42 & & -1.36 & & $\mathrm{CCDC} 102 \mathrm{~A}$ & $\begin{array}{l}\text { Coiled-coil domain-containing } \\
\text { protein } 102 \mathrm{~A}\end{array}$ & myosin complex, motor activity \\
\hline 1.30 & & 1.31 & 1.21 & 1.30 & & NEK7 & $\begin{array}{l}\text { Serine/threonine-protein kinase } \\
\text { Nek7 }\end{array}$ & protein kinase, mitotic cell cycle progression \\
\hline 1.42 & & 1.43 & & 1.29 & & $F H L 1$ & $\begin{array}{l}\text { Four and a half LIM domains } \\
\text { protein } 1\end{array}$ & developmental protein, cell differentiation \\
\hline 1.19 & & 1.26 & & & 1.20 & PITPNB & $\begin{array}{l}\text { Phosphatidylinositol transfer } \\
\text { protein beta isoform }\end{array}$ & $\begin{array}{l}\text { transfer of phosphatidylinositol between membranes, } \\
\text { retrograde vesicle-mediated transp ort, from Golgi to endoplasmic reticulum }\end{array}$ \\
\hline-1.25 & & -1.32 & & -1.38 & & PTPN1 & $\begin{array}{l}\text { Tyrosine-protein phosphatase non- } \\
\text { receptor type } 1\end{array}$ & $\begin{array}{l}\text { signal transduction, endoplasmic reticulumunfolded protein response, } \\
\text { actin cytoskeleton reorganization }\end{array}$ \\
\hline-1.21 & & -1.27 & & -1.39 & & PTPN1 1 & $\begin{array}{l}\text { Tyrosine-protein phosphatase non- } \\
\text { receptor type } 11\end{array}$ & signal transduction, positive regulation of MAPK pathway \\
\hline-1.39 & -1.28 & -1.24 & -1.30 & -1.30 & -1.27 & SERPINE1 & Plasminogen activ ator inhibitor 1 & $\begin{array}{l}\text { serine protease inhibitor, a primary inhibitor of tissue-type plasminogen activ ator } \\
\text { (PLAT) and urokinase-type plasminogen activ ator, regulator of cell migration }\end{array}$ \\
\hline \multirow[t]{2}{*}{-1.20} & & -1.21 & & -1.23 & & SLC12A7 & Solute carrier family 12 member 7 & ion transp ort, chemical synaptic transmission, cell volume homeostasis \\
\hline & -1.22 & -1.36 & -1.45 & -1.39 & & $\operatorname{SHX7}$ & Sorting nexin-7 & lipid binding, intracellular trafficking \\
\hline \multirow[t]{2}{*}{-1.18} & & -1.29 & & -1.36 & & MMP14 & Matrix metalloproteinase-14 & $\begin{array}{l}\text { endopeptidase, degradation of extracellular matrix components, } \\
\text { astrocyte cell migration }\end{array}$ \\
\hline & -1.18 & & -1.22 & & -1.19 & FTGS1 & Prostaglandin $\mathrm{G} / \mathrm{H}$ synthase 1 & peroxidase activity, response to inflammatory and oxidative stress \\
\hline 1.21 & & 1.23 & & 1.21 & & GZMB & Granzyme B & immune related protein, involved in apoptosis \\
\hline 1.43 & & & & 1.27 & & NARS & $\begin{array}{l}\text { Asparagine--tRNA ligase, } \\
\text { cytoplasmic }\end{array}$ & protein synthesis, immune response in a CCR3-dependent manner \\
\hline 1.34 & & 1.29 & & 1.17 & & RNH1 & Ribonuclease inhibitor & mRNA catabolic process, regulation of angiogenesis, redox homeostasis \\
\hline 1.39 & & 1.46 & & & 1.54 & $\mathrm{CA} 3$ & Carbonic anhydrase 3 & carbonate dehydratase activity, response to oxidative stress \\
\hline 1.35 & & 1.30 & & 1.31 & 1.20 & PSAP & Prosaposin & myelinotrophic and neurotrophic factor, lysosomal degradation of sphingolipids \\
\hline 1.25 & & 1.25 & & 1.26 & & PRPS1 & $\begin{array}{l}\text { Ribose-phosphate } \\
\text { pyrophosphokinase } 1\end{array}$ & $\begin{array}{c}\text { catalyzes the synthesis of phosphoribosylpyrophosphate (PRPP) - essential for } \\
\text { nucleotide synthesis }\end{array}$ \\
\hline \multicolumn{5}{|c|}{ fold change $\leq-1.20$} & & & & \\
\hline \multicolumn{5}{|c|}{$-1.20<$ fold change $<-1.17$} & & & & \\
\hline & \multicolumn{4}{|c|}{$1.17<$ fold change $<1.20$} & & & & \\
\hline & \multicolumn{4}{|c|}{ fold change $\geq 1.20$} & & & & \\
\hline
\end{tabular}

Proteins MYH9, CFL1, Dstn have been identified in several spots on the gels 
markers, have been associated with negative symptoms of schizophrenia [43]. Despite many studies that confirm a decrease in cytokine levels in response to antipsychotic drugs [44], there are also contradictory reports [45]. Moreover, the immunomodulatory role of antipsychotics is much more complicated than just restoration of retained cytokines to normal levels [46].

\section{Haloperidol Induced the Inhibition of the Ciliary Trophic Factor Signaling}

Canonical pathways analysis revealed inhibition of the ciliary neurotrophic factor (CNTF) signaling after 12-h incubation with haloperidol ( $\mathrm{z}$-score $=-2.00$, Table 2 ), what was based on downregulation of the following proteins: mTOR kinase (MTOR), MAP kinase kinase 2 (MAP2K2), tyrosineprotein phosphatase non-receptor type 11(PTPN11), PI3kinase type 3 (PIK3C3). CNTF belongs to the interleukin-6 (IL-6) cytokine family which promotes neurite outgrowth in the hypothalamus and hippocampus [47], increases neuronal survival after injury [48] and enhances cognitive and memory function in rodent models $[49,50]$. CNTF also regulates D2-receptor-dependent adult neurogenesis, so modulating CNTF has been suggested as potential therapeutic strategy for normalizing dopaminergic and neurogenic deficits [51]. The association of CNTF-encoding gene polymorphism with schizophrenia has been debated since the 1990s [52-54]. Certain types of CNTF-encoding gene polymorphisms cause patients to respond positively to treatment with iloperidone, an atypical antipsychotic [55]. It has been postulated by Mori et al. that D2 receptor activation stimulates CNTF expression [51], thus it could be expected that haloperidol, D2 receptor antagonist, may have a negative impact on CNTF level.

\section{Risperidone had an Inhibitory Effect on the Acute Phase Response Signaling}

The canonical pathway analysis of proteome changes induced by risperidone, indicated the inhibition of the acute phase response signaling ( $\mathrm{z}$-score $=-2.24$, Table 2 ). The conclusion was drawn from the observed downregulation of proteins produced in response to inflammation: interleukin-1 receptor antagonist protein (IL1RN), SHC-transforming protein 1 (SHC1), mTOR kinase (MTOR), plasminogen activator inhibitor 1 (SERPINE1). Their concentration has also been shown to be higher in schizophrenia patients [56-58]. Cytokine IL1RN modulates a variety of interleukin 1 related immune and inflammatory responses. It is released in response to IL- $1 \beta$ and IL- 6 to reduce the action of IL- 1 by binding to its receptor [59]. The elevation of IL1RN protein has been shown in schizophrenic patients [60-62]. However, there are also reports of a reduction in IL1RN levels in the prefrontal cortex of schizophrenic patients [63]. It was shown that the risperidone therapy caused a decrease in the level of IL1RN [64], while an increase in the level of IL1RA was found after treatment with haloperidol and clozapine $[65,66]$. In another study, the level of the protein did not change under the influence of various antipsychotics [67]. The inhibitory effect of risperidone on proinflammatory signaling is also supported by another type of IPA analysis. Searching for upstream regulators revealed that the number of changes detected in our experiment can be explained by downregulation of TNF and TGF- $\beta 1$ cytokines (Fig. 2a, b).

\section{Alterations in PC12 Proteome Induced by Clozapine}

The common mechanism of antipsychotic drug action is dopamine D2 receptor blockage and resulting activation of cyclic AMP/protein kinase A pathway. Numerous reports showed the increase of PKA signaling induced by clozapine and other antipsychotics [68-70]. It was also observed in studies on rats that haloperidol and clozapine impact PKA phosphorylation differently and depending on the method of drug administration-single or chronic [68]. Here, the canonical pathway analysis showed that after $12 \mathrm{~h}$ of incubation with clozapine (CLO12 experimental group), the protein kinase A signaling was still activated (PKA, $\mathrm{z}$-score $=2.83$, Table 2 ). PKA controls a variety of processes through phosphorylation of transcription factor CREB, protein phosphatases, glutamatergic receptors, and it is involved in mammalian target of rapamycin (mTOR) activation [71, 72]. PKA signaling has been also implicated in the pathology of schizophrenia [73].

Part of the differential proteins assigned to the PKA signaling was also related by the IPA with the nuclear factor of activated T-cells (NFAT) pathway which influences cardiac hypertrophy (z-score $=2.24$, Table 2 ). Calmodulin-dependent protein kinase 2, that was found upregulated, is a core mechanism for promoting cardiomyopathy and myocarditis, which are potentially fatal side effects of clozapine [74-76]. Moreover, calcineurin (one of its subunits, PPP3R1, was found increased) directly regulates the activity of CREB and NFAT transcription factors associated with cognitive functions disturbed in schizophrenia [77].

In the CLO12 group, we also found increased abundance of key regulators of protein synthesis: eight ribosomal proteins and translation initiation factor EIF2B4. They were assigned to the eukaryotic initiation factor 2 pathway ( $\mathrm{z}$-score $=2.83$, Table 2$)$. In olfactory cells derived from schizophrenia patients, English et al. observed a significant reduction in global translation rate together with dysregulation of EIF2, EIF4, and mTOR signaling pathways [78]. However, the same research team detected an increase in the level of translation-related proteins in patients' progenitor cells [79], suggesting a cell type-specific effect. Recent 
Table 2 Signal transmission pathways inhibited (blue) or activated (orange) under the influence of 12 or $24 \mathrm{~h}$ treatment with clozapine (CLO), risperidone (RIS), and haloperidol (HAL)

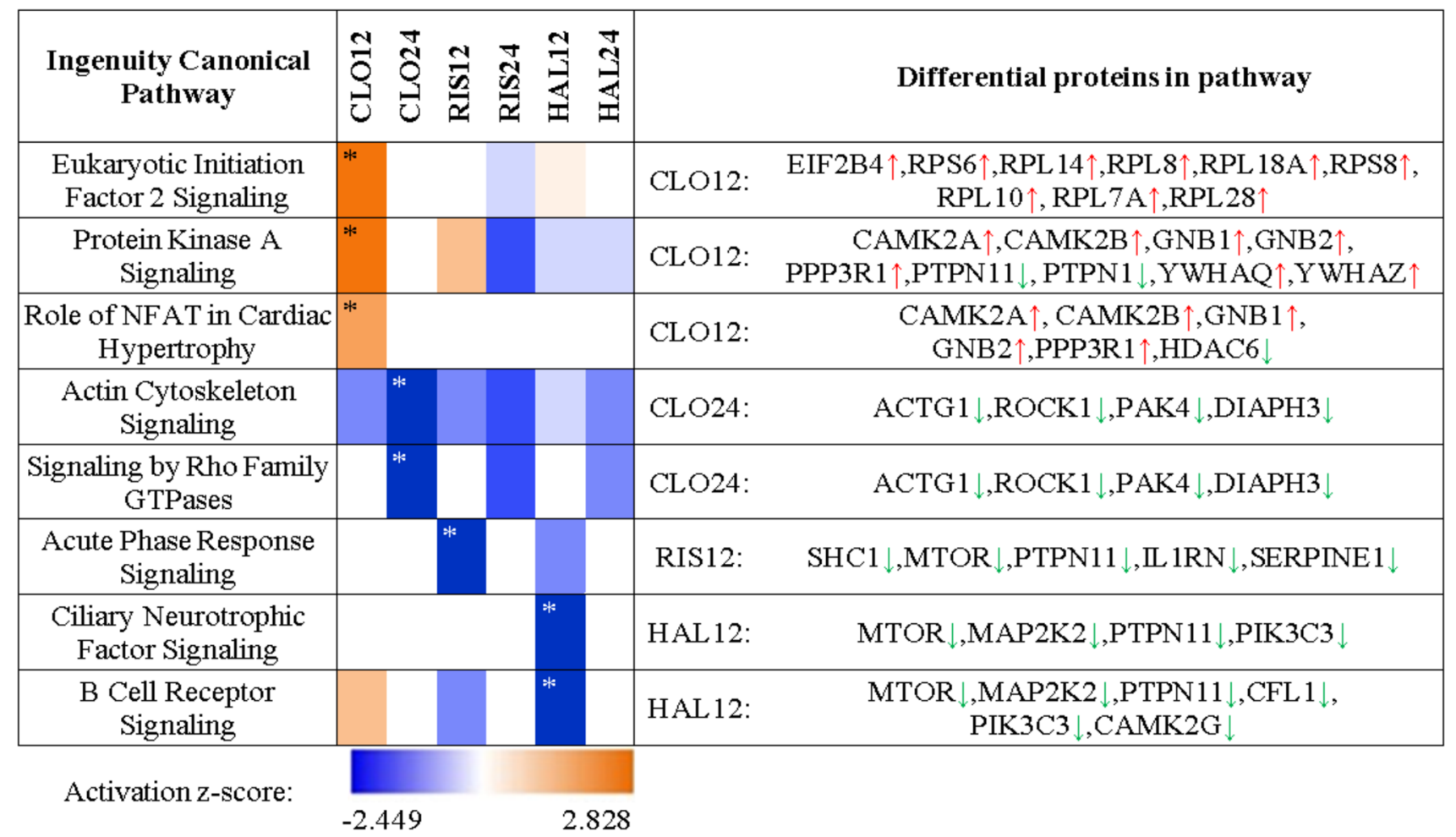

Table generated through the use of IPA

*Significant regulation: $\mathrm{z}$-score $\leq-2.00$ or $\geq 2.00$ and $\mathrm{p}$-value $<0.01$

studies have highlighted that an imbalance in the protein synthesis process contributes to neurodevelopmental disorders [80-82]. Proteomic studies on cultured striatal neurons exposed to haloperidol also revealed activation of mTORC1dependent translation [83]. In the mentioned study, the level of several translation-related proteins, including eukaryotic elongation factor 2 (eEF2), was shown to be elevated. To check if changes in translational machinery are also induced by atypical drugs, the level of eEF2 was tested for two representatives of atypical drugs, risperidone and amisulpride. The increase was shown, however, with less stringent statistical criteria $(\mathrm{p}<0.1)$ [83]. In our study, activation of protein synthesis pathway was found as significant for clozapine, however, there were also some ribosomal proteins upregulated in the haloperidol group (see Supplementary file 2).

Differential proteins from each experimental group were combined in functional networks through the use of IPA. Detailed results are included in Supplementary file 3 . Figure $2 \mathrm{c}$ shows a network related to neurological diseases that emerged from the CLO12 group. Several proteins included in the network are known to be downregulated in schizophrenia patients, while in our study they were found to be upregulated after clozapine treatment: $14-3-3$ protein zeta/delta (YWHAZ), an acidic leucine-rich nuclear phosphoprotein 32 family member A (Anp32a), cytosolic purine 5'-nucleotidase (NT5C2) [84-86]. In addition, the latest study reveals that NT5C2 regulates AMP-activated protein kinase (AMPK) signaling, ribosomal protein S6 (RPS6), and protein translation in neural stem cells [87]. AMPK was also found to be upregulated in the CLO12 group, which confirms the results of Kim et al. [88]. AMPK plays a central role in controlling lipid metabolism and its elevated level may be one of the reasons for metabolic side effects which are induced by clozapine more often than by other antipsychotics [88].

The most prominent finding in the CLO24 experimental group (cells incubated for $24 \mathrm{~h}$ with clozapine) was an inhibition of the actin cytoskeleton signaling and Rho proteins signaling ( $\mathrm{z}$-score $=-2.00$, Table 2 ), which is consistent with the results of our previous studies conducted on the cortex of rats treated with clozapine [31] and with the outcome of the experiment performed on MK-801 cells by Martins-de-Souza et al. [89]. Proteomic study on oligodendrocytes showed that clozapine and haloperidol affected proteins involved with the actin cytoskeleton and EIF2 signaling [90]. The polymerization of actin is responsible for the synapse plasticity and morphological changes of dendritic spines in response to stimuli [91]. In schizophrenia, synaptic 
Fig. 2 Tumor necrosis factor (TNF) as the primary regulator of cell changes after incubation with antipsychotic drugs: clozapine $12 \mathrm{~h}$ (CLO12), $\mathrm{z}$-score $=-2.42$; risperidone 12 h (RIS12), z-score $=-2.04$; haloperidol $24 \mathrm{~h}$ (HAL24), $\mathrm{z}$-score $=-2.45$ (A). Transforming growth factor beta 1 (TGF- $\beta 1$ ) as an upstream regulator of proteome changes after incubation with antipsychotics: clozapine $24 \mathrm{~h}$ (CLO24), z-score $=-1.96$; risperidone $12 \mathrm{~h}$, $\mathrm{z}$-score $=-1.88$; haloperidol $12 \mathrm{~h}$ (HAL12), $\mathrm{z}$-score $=-2.16(\mathbf{B})$. Emerged network identified by IPA based on differential proteins after $12 \mathrm{~h}$ of incubation with clozapine (C). Full and dashed lines depict direct and indirect connections, respectively a

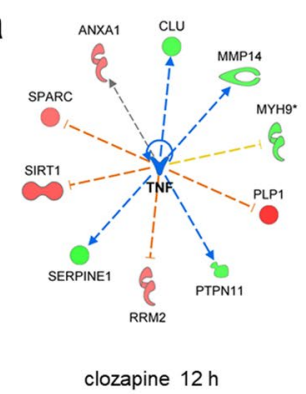

b

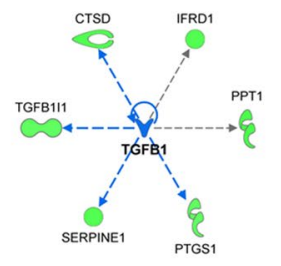

CLO24
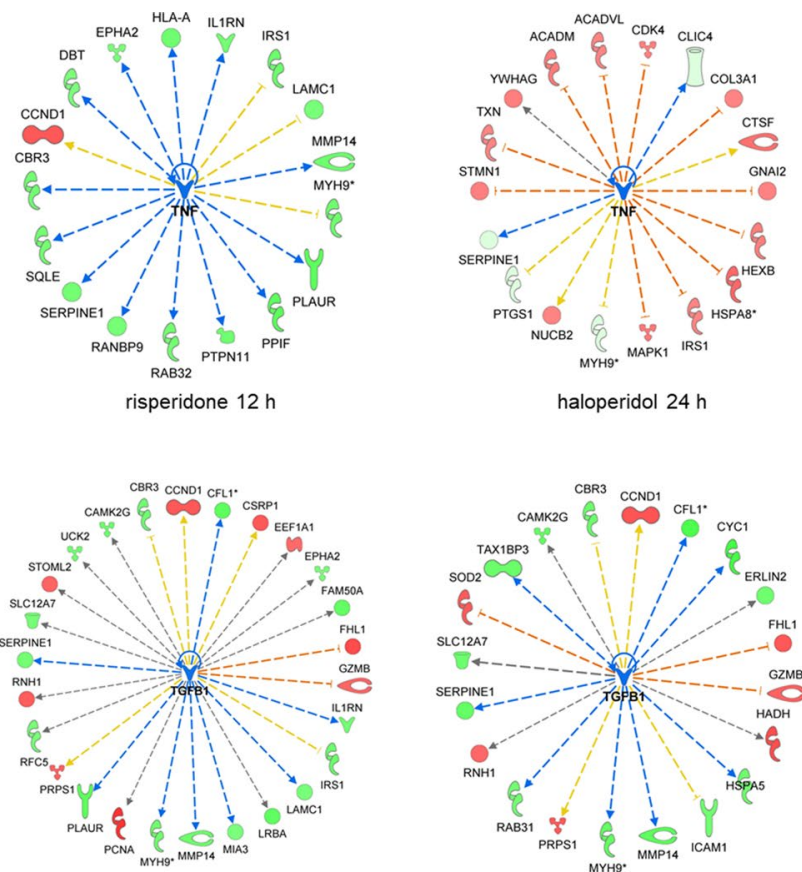

RIS12

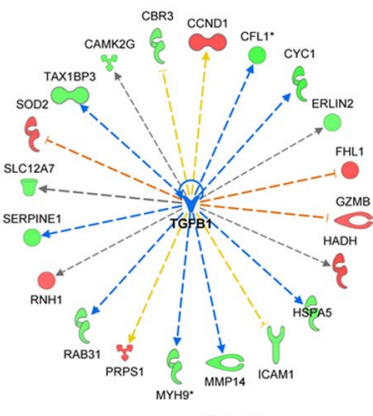

HAL12

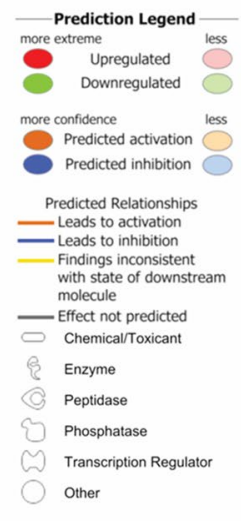

reorganization disturbances are observed in long-term potentiation (LTP) and long-term depression (LTD) [92, 93]. In patients with schizophrenia, altered level of actin-related proteins was frequently reported in the literature, however, the direction of these changes was ambiguous [94-99]. The long-term action of clozapine seems to result in changes of cytoskeletal organisation, probably leading to the restoration of synapse plasticity altered in schizophrenia.

\section{Suggested Contribution of the mTOR Signaling in the Clozapine Action}

In Fig. 3, the key alterations revealed after clozapine treatment in two time points were integrated into the network on the basis of the literature knowledge. During proteomic dataset analysis, several premises emerged indicating that Akt kinase and mTOR complexes play a superior role in clozapine signal transduction. Recently, disturbances in mTOR signaling are emerging as important factors in schizophrenia and other neurological diseases [100-104].

The mTORC1 controls translation, cell growth, and proliferation, thus increased levels of ribosomal proteins and the eIF-2B translation initiation factor may result from mTORC1 activation [102]. This is reverse to the changes observed in schizophrenic brains. The smaller soma size of patients' neurons was linked to decreased mTORC1 signaling, while Aktl gene expression was downregulated [104]. In mice that display manic-like behaviors, transcriptomic analysis showed downregulation of mTORC1 signaling [105]. 
Interestingly, the ingenuity upstream analysis tool showed that the upregulation of ribosomal proteins after $12 \mathrm{~h}$ incubation with clozapine, may be caused by a decrease in the activity of the Rictor protein (z-score $=-2.13)$, as it was shown in Rictor-knockout mice [106]. Rictor is a key regulatory subunit of mTOR complex 2 (mTORC2) [107]. This complex regulates cellular metabolism as well as stimulates the formation of actin filaments through interaction with RhoA proteins, Rac1, Cdc42 and C $\alpha$ protein kinase (PKC $\alpha)$ [108]. Therefore, the decrease in the level of actin-binding proteins and in general the promotion of actin depolymerization may be triggered by inhibition of the mTORC2 pathway [109]. Siuta et al. showed that neuronal mTORC2 dysfunction is sufficient to generate cortical hypodopaminergia (postulated as present in schizophrenia) and schizophrenia-linked behaviors (sensorimotor gating deficits) [107]. However, Carson et al. demonstrated that mice with conditional knockout of Rictor had reduced anxiety-like behavior, but the negative effect of this knockout was brain development disorder and smaller volume of brain structures [110]. Thus, inhibition of Rictor-controlled pathways induced by clozapine may adjust the dopaminergic balance in the schizophrenic brain. In the later stages, mTORC1 regulates autophagy, mitochondrial function and lipid synthesis [111]. Therefore, dysregulation of mTOR signaling is associated with various diseases such as obesity and type 2 diabetes, which are often cumbersome side-effects of clozapine $[112,113]$. Intriguing, the mTOR itself has been found downregulated in the risperidone and haloperidol treated group (see Table 2). Moreover, regulation of translation-related machinery as well as actin cytoskeleton signaling was not recognized for these drugs as significant by IPA. This looks contrary to the study of Bowling et al. showing the activation of mTORC1-dependent translation after treatment with haloperidol in cultured striatal neurons [83]. However, the other group found that olanzapine (atypical antipsychotic drug), but not haloperidol activates mTORC1 signaling in rat primary hippocampal neurons [114]. Similarly, Deslauriers et al. reported no significant effect on mTOR activation for haloperidol and amisulpride in SH-SY5Y human neuroblastoma cells [115]. Thus, it seems that there is no universal mechanism regarding impact of haloperidol on mTOR signaling. This may depend on the model used for the study as well as experimental conditions, such as drug concentration or duration of treatment.

\section{Limitations/Rationale of Using PC12 Cells as a Model Research System}

To study antipsychotic drug action, we used the PC12 cell line, which is one of the most commonly used in neuroscience research. The main limitation of the in vitro cell culture system is the fact that it definitely cannot reflect interactions between different cell types and between cells and extracellular matrix which take place in the brain. There is no feedback from other types of cells and body fluids. However, we chose PC12 cell line as the simplest model to eliminate the complexity of the nervous system in the study. The advantages of in vitro cell culture systems are controlled environment and reduced experimental variation which could
Fig. 3 A potential network of interactions of differential proteins identified in $\mathrm{PC} 12$ cells under the influence of 12 and $24 \mathrm{~h}$ incubation with clozapine. An arrow $(\uparrow)$ indicates stimulation whereas a hammerhead $(T)$ indicates inhibition. Some critical pathways have been omitted for clarity

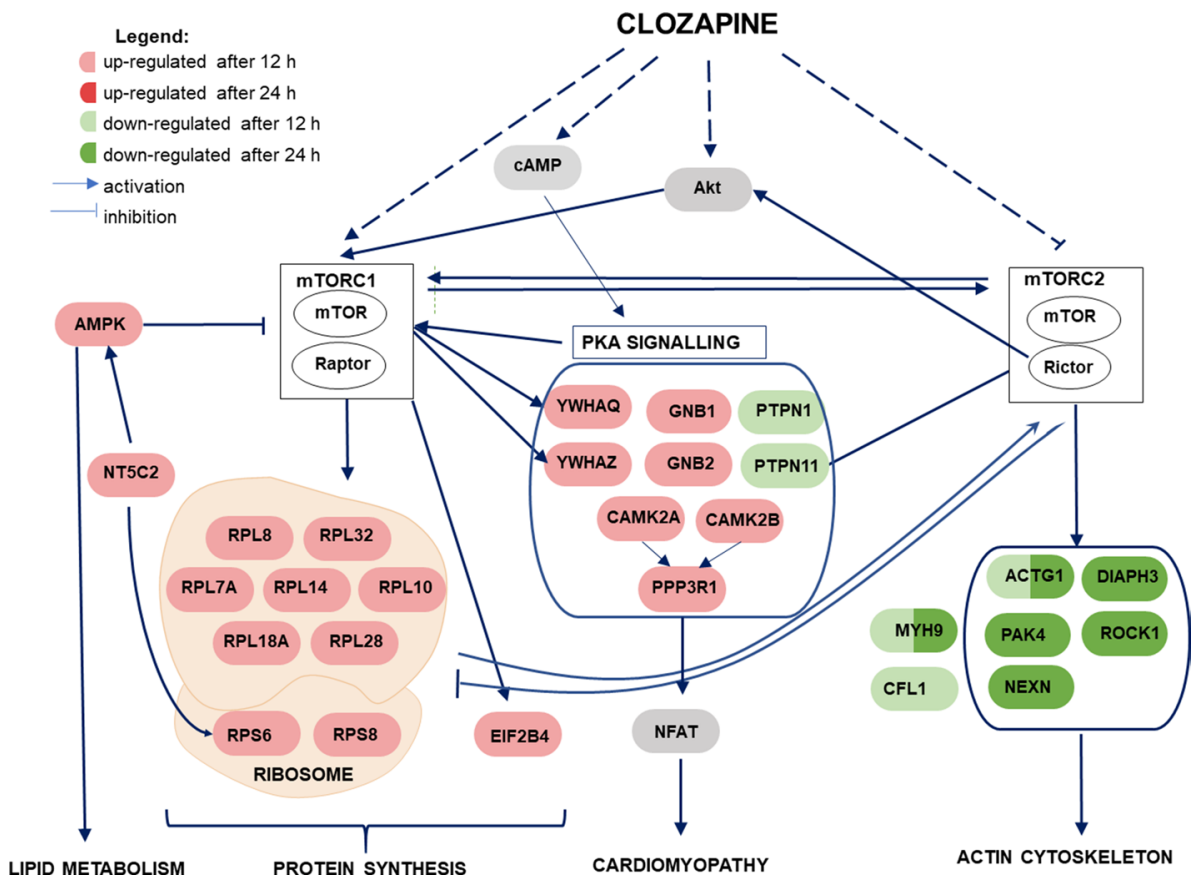


reliably yield better quality, more accurate results. In our previous experiments, we studied antipsychotic drug action on rat brain tissue and the proteome changes revealed were very subtle $[31,116]$. Here, we reached for naïve PC12 cell line, to work with homogenous cell population to increase the chances of revealing the potential changes in protein profile. However, detected changes were still small, what unequivocally proves that antipsychotic drugs' impact on the protein profiles is very subtle. We also did not treat PC12 cells with nerve growth factor to avoid additional variables. The similar model was used by Tejedor-Real et al. They observed similar changes in dopamine synthesis pathway (tyrosine hydroxylase) in the rat brain and PC12 cells after clozapine administration [21]. PC12 was also used as dopamine cell model [117]. PC12 cells express a high level of glucocorticoid receptors therefore they were utilized for hyperactivation of hypothalamic-pituitary-adrenal (HPA) axis relevant studies [118].

\section{Concluding Remarks}

Understanding the molecular mechanism of antipsychotic drugs remains an urgent issue that has been studied for the last 60 years without conclusive outcomes. However, the development of analytical techniques brings us closer to this goal. In our study, we applied two high-throughput proteomic approaches which enabled to explore the antipsychotic impact on cells at the pathway level. As alterations in protein profile revealed in our study have often not been linked to antipsychotics before, we also discuss it in the context of schizophrenia. All tested drugs seemed to stimulate a beneficial process of reducing inflammation, however, by activating different biochemical pathways. Additionally, for risperidone, pathway analysis showed inhibitory effect of acute phase response. In the case of haloperidol, the changes in the proteome indicated inhibition of ciliary trophic factor signaling. The 12-h incubation with clozapine caused up-regulation of protein kinase A signaling and translation machinery. After $24 \mathrm{~h}$ of treatment with clozapine, the inhibition of the actin cytoskeleton signaling and Rho proteins signaling was revealed. The observed changes suggest a central role of kinase mTOR in clozapine signal transduction. Decreased abundance of actin-binding proteins could be a result of inhibition of mTORC2 pathway, while stimulation of translation could be an effect of the mTORC1 pathway activation. On the other hand, the upregulation of calmodulin-dependent protein kinase 2 and AMPK signaling could be linked with adverse effects of clozapine administration. The most interesting question during the investigation was to catch the unique effectiveness of clozapine and the study revealed the importance of mTOR signaling for this drug. However, further biochemical analyses are required to explore this issue.

Supplementary Information The online version contains supplementary material available at https://doi.org/10.1007/s11064-021-03348-4.

Acknowledgements This work was supported by Grant UMO2013/09/N/NZ3/00202 to UJ from the Polish National Science Centre. SKK acknowledges additionally the support by the Polish National Science Centre (UMO-2017/25/B/NZ4/01403). The MS measurements were performed using a Q-Exactive purchased from POIG.02.01.0012-167/08 Project, Malopolska Centre of Biotechnology. Faculty of Biochemistry, Biophysics and Biotechnology is a partner of the Leading National Research Center (KNOW) supported by the Ministry of Science and Higher Education.

Funding This work was supported by Grant UMO-2013/09/N/ NZ3/00202 to UJ from the Polish National Science Centre. SKK acknowledges additionally the support by the Polish National Science Centre (UMO-2017/25/B/NZ4/01403). The MS measurements were performed using a Q-Exactive purchased from POIG.02.01.00-12167/08 Project, Malopolska Centre of Biotechnology. Faculty of Biochemistry, Biophysics and Biotechnology is a partner of the Leading National Research Center (KNOW) supported by the Ministry of Science and Higher Education.

Data Availability The MS proteomics data have been deposited to the ProteomeXchange Consortium via the PRIDE [1] partner repository with the dataset identifier PXD014422.

\section{Declarations}

Conflict of interest The authors declare that they have no conflict of interest.

Consent for Publication All authors gave consent for publication.

Open Access This article is licensed under a Creative Commons Attribution 4.0 International License, which permits use, sharing, adaptation, distribution and reproduction in any medium or format, as long as you give appropriate credit to the original author(s) and the source, provide a link to the Creative Commons licence, and indicate if changes were made. The images or other third party material in this article are included in the article's Creative Commons licence, unless indicated otherwise in a credit line to the material. If material is not included in the article's Creative Commons licence and your intended use is not permitted by statutory regulation or exceeds the permitted use, you will need to obtain permission directly from the copyright holder. To view a copy of this licence, visit http://creativecommons.org/licenses/by/4.0/.

\section{References}

1. Perez-Riverol Y, Csordas A, Bai J et al (2019) The PRIDE database and related tools and resources in 2019: improving support for quantification data. Nucleic Acids Res 47:D442-D450. https://doi.org/10.1093/nar/gky1106

2. Bowling H, Santini E (2016) Unlocking the molecular mechanisms of antipsychotics-a new frontier for discovery. Swiss Med Wkly 146:w14314. https://doi.org/10.4414/smw.2016. 14314 
3. Ackenheil M, Weber K (2002) Developments in antipsychotic therapy with regard to hypotheses for schizophrenia. Dialogues Clin Neurosci 4:426-431

4. Girgis R, Javitch J, Lieberman J (2008) Antipsychotic drug mechanisms: links between therapeutic effects, metabolic side effects and the insulin signaling pathway. Mol Psychiatry 13:918-929. https://doi.org/10.1038/mp.2008.40

5. Molteni R, Calabrese F, Racagni G et al (2009) Antipsychotic drug actions on gene modulation and signaling mechanisms. Pharmacol Ther 124:74-85. https://doi.org/10.1016/j.pharm thera.2009.06.001

6. Kowalchuk C, Kanagasundaram P, Belsham DD, Hahn MK (2019) Antipsychotics differentially regulate insulin, energy sensing, and inflammation pathways in hypothalamic rat neurons. Psychoneuroendocrinology 104:42-48. https://doi.org/ 10.1016/j.psyneuen.2019.01.029

7. Numata S, Umehara H, Ohmori T, Hashimoto R (2018) Clozapine pharmacogenetic studies in schizophrenia: efficacy and agranulocytosis. Front Pharmacol. https://doi.org/10.3389/ fphar.2018.01049

8. Lally J, MacCabe JH (2015) Antipsychotic medication in schizophrenia: a review. Br Med Bull 114:169-179. https://doi.org/ 10.1093/bmb/ldv017

9. Wenthur CJ, Lindsley CW (2013) Classics in chemical neuroscience: clozapine. ACS Chem Neurosci 4:1018-1025. https:// doi.org/10.1021/cn400121z

10. Aringhieri S, Carli M, Kolachalam S et al (2018) Molecular targets of atypical antipsychotics: from mechanism of action to clinical differences. Pharmacol Ther 192:20-41. https://doi. org/10.1016/j.pharmthera.2018.06.012

11. Donohoe DR, Phan T, Weeks K et al (2008) Antipsychotic drugs up-regulate tryptophan hydroxylase in ADF neurons of Caenorhabditis elegans: role of calcium-calmodulin-dependent protein kinase II and transient receptor potential vanilloid channel. J Neurosci Res 86:2553-2563. https://doi.org/10. 1002/jnr.21684

12. Lu XH, Dwyer DS (2005) Second-generation antipsychotic drugs, olanzapine, quetiapine, and clozapine enhance neurite outgrowth in PC12 cells via PI3K/AKT, ERK, and pertussis toxin-sensitive pathways. J Mol Neurosci 27:43-64

13. Greene LA, Tischler AS (1976) Establishment of a noradrenergic clonal line of rat adrenal pheochromocytoma cells which respond to nerve growth factor. Proc Natl Acad Sci USA 73:2424-2428. https://doi.org/10.1073/pnas.73.7.2424

14. Zhu WH, Conforti L, Millhorn DE (1997) Expression of dopamine D 2 receptor in PC-12 cells and regulation of membrane conductances by dopamine. Am J Physiol Cell Physiol 273:C1143-C1150. https://doi.org/10.1152/ajpcell.1997.273.4. C1143

15. Zachor DA, Moore JF, Brezausek C et al (2000) Cocaine inhibits NGF-induced PC12 cells differentiation through D(1)-type dopamine receptors. Brain Res 869:85-97. https://doi.org/10. 1016/S0006-8993(00)02355-6

16. Pothos EN, Przedborski S, Davila V et al (1998) D2-like dopamine autoreceptor activation reduces quantal size in PC12 cells. J Neurosci 18:5575-5585. https://doi.org/10.1523/ JNEUROSCI.18-15-05575.1998

17. Quinn JC, Johnson-Farley NN, Yoon J, Cowen DS (2002) Activation of extracellular-regulated kinase by 5-hydroxytryptamine(2A) receptors in PC12 cells is protein kinase $\mathrm{C}$-independent and requires calmodulin and tyrosine kinases. J Pharmacol Exp Ther 303:746-752. https://doi.org/ 10.1124/jpet.102.038083

18. Berkeley JL, Levey AI (2000) Muscarinic activation of mitogenactivated protein kinase in PC12 cells. J Neurochem 75:487-493. https://doi.org/10.1046/j.1471-4159.2000.0750487.x
19. Kashem MA, Ummehany R, Ukai W et al (2009) Effects of typical (haloperidol) and atypical (risperidone) antipsychotic agents on protein expression in rat neural stem cells. Neurochem Int 55:558-565. https://doi.org/10.1016/j.neuint.2009.05.007

20. Ahmed EU, Ahmed S, Ukai W et al (2012) Antipsychotic induced alteration of growth and proteome of rat neural stem cells. Neurochem Res 37:1649-1659. https://doi.org/10.1007/ s11064-012-0768-3

21. Tejedor-Real P, Vogel R, Mallet J, Biguet NF (2005) Gi/Go protein-dependent presynaptic mechanisms are involved in clozapine-induced down-regulation of tyrosine hydroxylase in PC12 cells. J Neurosci Res 81:739-745. https://doi.org/10.1002/ jnr.20585

22. Walss-Bass C, Weintraub ST, Hatch J et al (2008) Clozapine causes oxidation of proteins involved in energy metabolism: a possible mechanism for antipsychotic-induced metabolic alterations. Int J Neuropsychopharmacol 11:1097-1104. https://doi. org/10.1017/S1461145708008882

23. Bradford MM (1976) A rapid and sensitive method for the quantitation of microgram quantities of protein utilizing the principle of protein-dye binding. Anal Biochem 72:248-254. https://doi. org/10.1016/0003-2697(76)90527-3

24. McDowell GS, Gaun A, Steen H (2013) iFASP: combining isobaric mass tagging with filter-aided sample preparation. J Proteome Res 12:3809-3812. https://doi.org/10.1021/pr400032m

25. Rappsilber J, Mann M, Ishihama Y (2007) Protocol for micropurification, enrichment, pre-fractionation and storage of peptides for proteomics using StageTips. Nat Protoc 2:1896-1906. https://doi.org/10.1038/nprot.2007.261

26. Nesvizhskii AI, Keller A, Kolker E, Aebersold R (2003) A statistical model for identifying proteins by tandem mass spectrometry. Anal Chem 75:4646-4658. https://doi.org/10.1021/ac034 1261

27. Shadforth IP, Dunkley TPJ, Lilley KS, Bessant C (2005) i-Tracker: for quantitative proteomics using iTRAQ ${ }^{\mathrm{TM}}$. BMC Genom 6:1-6. https://doi.org/10.1186/1471-2164-6-145

28. Jankowska U, Latosinska A, Skupien-Rabian B et al (2016) Optimized procedure of extraction, purification and proteomic analysis of nuclear proteins from mouse brain. J Neurosci Methods 261:1-9. https://doi.org/10.1016/j.jneumeth.2015.12.002

29. Kedracka-Krok S, Swiderska B, Bielecka-Wajdman AM et al (2018) Impact of imipramine on proteome of rat primary glial cells. J Neuroimmunol 320:25-37. https://doi.org/10.1016/j.jneur oim.2018.04.008

30. Aude-Garcia C, Collin-Faure V, Luche S, Rabilloud T (2011) Improvements and simplifications in in-gel fluorescent detection of proteins using ruthenium II tris-(bathophenanthroline disulfonate): the poor man's fluorescent detection method. Proteomics 11:324-328. https://doi.org/10.1002/pmic.201000370

31. Kedracka-Krok S, Swiderska B, Jankowska U et al (2015) Clozapine influences cytoskeleton structure and calcium homeostasis in rat cerebral cortex and has a different proteomic profile than risperidone. J Neurochem 132:657-676. https://doi.org/10.1111/ jnc. 13007

32. Krämer A, Green J, Pollard J, Tugendreich S (2014) Causal analysis approaches in ingenuity pathway analysis. Bioinformatics 30:523-530. https://doi.org/10.1093/bioinformatics/btt703

33. Jungblut PR, Holzhütter HG, Apweiler R, Schlüter H (2008) The speciation of the proteome. Chem Cent J 2:1-10. https://doi.org/ 10.1186/1752-153X-2-16

34. Wu WW, Wang G, Baek SJ, Shen RF (2006) Comparative study of three proteomic quantitative methods, DIGE, cICAT, and iTRAQ, using 2D gel- or LC-MALDI TOF/TOF. J Proteome Res 5:651-658. https://doi.org/10.1021/pr050405o

35. Kaltwaßer B, Schulenborg T, Beck F et al (2013) Developmental changes of the protein repertoire in the rat auditory brainstem: a 
comparative proteomics approach in the superior olivary complex and the inferior colliculus with DIGE and iTRAQ. J Proteomics 79:43-59. https://doi.org/10.1016/j.jprot.2012.11.018

36. Robbins ML, Roy A, Wang PH et al (2013) Comparative proteomics analysis by DIGE and iTRAQ provides insight into the regulation of phenylpropanoids in maize. J Proteomics 93:254275. https://doi.org/10.1016/j.jprot.2013.06.018

37. Jeffries CD, Perkins DO, Fournier M et al (2018) Networks of blood proteins in the neuroimmunology of schizophrenia. Transl Psychiatry 8:112. https://doi.org/10.1038/s41398-018-0158-y

38. Khan SS, Shah SJ, Klyachko E et al (2017) A null mutation in SERPINE1 protects against biological aging in humans. Sci Adv 3:eaao1617. https://doi.org/10.1126/sciadv.aao1617

39. Lijnen HR (2005) Pleiotropic functions of plasminogen activator inhibitor-1. J Thromb Haemost 3:35-45. https://doi.org/10. 1111/j.1538-7836.2004.00827.x

40. Etique N, Verzeaux L, Dedieu S, Emonard H (2013) Lrp-1: a checkpoint for the extracellular matrix proteolysis. Biomed Res Int. https://doi.org/10.1155/2013/152163

41. Beroun A, Mitra S, Michaluk P et al (2019) MMPs in learning and memory and neuropsychiatric disorders. Cell Mol Life Sci 76:3207-3228. https://doi.org/10.1007/s00018-019-03180-8

42. Lee YL, Hsiao CJ, Lin FL et al (2018) Haloperidol abrogates matrix metalloproteinase- 9 expression by inhibition of NF- $\mathrm{kB}$ activation in stimulated human monocytic cells. Mediat Inflamm. https://doi.org/10.1155/2018/9541459

43. Goldsmith DR, Haroon E, Miller AH et al (2018) TNF- $\alpha$ and IL-6 are associated with the deficit syndrome and negative symptoms in patients with chronic schizophrenia. Schizophr Res 199:281-284. https://doi.org/10.1016/j.schres.2018.02.048

44. Stapel B, Sieve I, Falk CS et al (2018) Second generation atypical antipsychotics olanzapine and aripiprazole reduce expression and secretion of inflammatory cytokines in human immune cells. J Psychiatr Res 105:95-102. https://doi.org/10.1016/j.jpsychires. 2018.08.017

45. Dinesh AA, Islam J, Khan J et al (2020) Effects of antipsychotic drugs: cross talk between the nervous and innate immune system. CNS Drugs 34:1229-1251. https://doi.org/10.1007/ s40263-020-00765-x

46. Pollmacher T, Haack M, Schuld A et al (2000) Effects of antipsychotic drugs on cytokine networks. J Psychiatr Res 34:369-382. https://doi.org/10.1016/S0022-3956(00)00032-7

47. Askvig JM, Leiphon LJ, Watt JA (2012) Neuronal activity and axonal sprouting differentially regulate CNTF and CNTF receptor complex in the rat supraoptic nucleus. Exp Neurol 233:243252. https://doi.org/10.1016/j.expneurol.2011.10.009

48. Kang SS, Keasey MP, Cai J, Hagg T (2012) Loss of neuronastroglial interaction rapidly induces protective CNTF expression after stroke in mice. J Neurosci 32:9277-9287. https://doi.org/ 10.1523/JNEUROSCI.1746-12.2012

49. Garcia P, Youssef I, Utvik JK et al (2010) Ciliary neurotrophic factor cell-based delivery prevents synaptic impairment and improves memory in mouse models of Alzheimer's disease. J Neurosci 30:7516-7527. https://doi.org/10.1523/JNEUROSCI. 4182-09.2010

50. Jia C, Brown RW, Malone HM et al (2019) Ciliary neurotrophic factor is a key sex-specific regulator of depressive-like behavior in mice. Psychoneuroendocrinology 100:96-105. https://doi.org/ 10.1016/j.psyneuen.2018.09.038

51. Mori M, Jefferson JJ, Hummel M, Garbe DS (2008) CNTF: a putative link between dopamine D2 receptors and neurogenesis. J Neurosci 28:5867-5869. https://doi.org/10.1523/JNEUROSCI. 1782-08.2008

52. Sakai T, Sasaki T, Tatsumi M et al (1997) Schizophrenia and the ciliary neurotrophic factor (CNTF) gene: no evidence for association. Psychiatry Res 71:7-10. https://doi.org/10.1016/ S0165-1781(97)00039-5

53. Thome J, Jösson E, Foley P et al (1997) Ciliary neurotrophic factor null mutation and schizophrenia in a Swedish population. Psychiatr Genet 7:79-82. https://doi.org/10.1097/00041444199722000-00004

54. Virgos C (2001) Association study of schizophrenia with polymorphisms at six candidate genes. Schizophr Res 49:65-71. https://doi.org/10.1016/S0920-9964(00)00106-7

55. Lavedan C, Volpi S, Polymeropoulos MH, Wolfgang CD (2008) Effect of a ciliary neurotrophic factor polymorphism on schizophrenia symptom improvement in an iloperidone clinical trial. Pharmacogenomics 9:289-301. https://doi.org/10.2217/14622 416.9.3.289

56. Maes M, Delange J, Ranjan R et al (1997) Acute phase proteins in schizophrenia, mania and major depression: modulation by psychotropic drugs. Psychiatry Res 66:1-11. https://doi.org/10. 1016/S0165-1781(96)02915-0

57. Morera AL, Henry M, García-Hernández A, Fernandez-López L (2007) Acute phase proteins as biological markers of negative psychopathology in paranoid schizophrenia. Actas Esp Psiquiatr 35:249-252

58. Yang Y, Wan C, Li H et al (2006) Altered levels of acute phase proteins in the plasma of patients with schizophrenia. Anal Chem 78:3571-3576. https://doi.org/10.1021/ac051916x

59. Potvin S, Stip E, Sepehry AA et al (2008) Inflammatory cytokine alterations in schizophrenia: a systematic quantitative review. Biol Psychiatry 63:801-808. https://doi.org/10.1016/j.biopsych. 2007.09.024

60. Miller BJ, Buckley P, Seabolt W et al (2011) Meta-analysis of cytokine alterations in schizophrenia: clinical status and antipsychotic effects. Biol Psychiatry 70:663-671. https://doi.org/10. 1016/j.biopsych.2011.04.013

61. Hylén U, Eklund D, Humble M et al (2020) Increased inflammasome activity in markedly ill psychiatric patients: an explorative study. J Neuroimmunol. https://doi.org/10.1016/j.jneuroim.2019. 577119

62. Lin Y, Peng Y, He S et al (2018) Serum IL-1ra, a novel biomarker predicting olanzapine-induced hypercholesterolemia and hyperleptinemia in schizophrenia. Prog Neuro-Psychopharmacol Biol Psychiatry 84:71-78. https://doi.org/10.1016/j.pnpbp.2018.01. 020

63. Toyooka K, Watanabe Y, Iritani S et al (2003) A decrease in interleukin-1 receptor antagonist expression in the prefrontal cortex of schizophrenic patients. Neurosci Res 46:299-307. https:// doi.org/10.1016/S0168-0102(03)00093-2

64. Maes M, Bosmans E, Ranjan R et al (1996) Lower plasma CC16, a natural anti-inflammatory protein, and increased plasma interleukin-1 receptor antagonist in schizophrenia: effects of antipsychotic drugs. Schizophr Res 21:39-50. https://doi.org/10.1016/ 0920-9964(96)00029-1

65. Song C, Lin AH, Kenis G, et al (2000) Immunosuppressive effects of clozapine and haloperidol: enhanced production of the interleukin-1 receptor antagonist. Schizophr Res 42:157-164. https://doi.org/10.1016/S0920-9964(99)00116-4

66. Sirota P, Meiman M, Herschko R, Bessler H (2005) Effect of neuroleptic administration on serum levels of soluble IL-2 receptor-alpha and IL-1 receptor antagonist in schizophrenic patients. Psychiatry Res 134:151-159. https://doi.org/10.1016/j.psychres. 2004.04.012

67. Akiyama K (1999) Serum levels of soluble IL-2 receptor alpha, IL-6 and IL-1 receptor antagonist in schizophrenia before and during neuroleptic administration. Schizophr Res 37:97-106. https://doi.org/10.1016/s0920-9964(98)00140-6 
68. Dwivedi Y, Rizavi HS, Pandey GN (2002) Differential effects of haloperidol and clozapine on [(3)H]cAMP binding, protein kinase A (PKA) activity, and mRNA and protein expression of selective regulatory and catalytic subunit isoforms of PKA in rat brain. J Pharmacol Exp Ther 301:197-209. https://doi.org/ 10.1124/jpet.301.1.197

69. Jeon S, Kim Y, Chung IW, Kim YS (2015) Clozapine induces chloride channel-4 expression through PKA activation and modulates CDK5 expression in SH-SY5Y and U87 cells. Prog Neuro-Psychopharmacol Biol Psychiatry 56:168-173. https:// doi.org/10.1016/j.pnpbp.2014.09.002

70. Turalba AV, Leite-Morris KA, Kaplan GB (2004) Antipsychotics regulate cyclic AMP-dependent protein kinase and phosphorylated cyclic AMP response element-binding protein in striatal and cortical brain regions in mice. Neurosci Lett 357:53-57. https://doi.org/10.1016/j.neulet.2003.11.059

71. Kvajo M, McKellar H, Gogos JA (2010) Molecules, signaling, and schizophrenia. Curr Top Behav Neurosci 4:629-656. https://doi.org/10.1007/7854_2010_41

72. Zhang B, Guo F, Ma Y et al (2017) Activation of D1R/PKA/ mTOR signaling cascade in medial prefrontal cortex underlying the antidepressant effects of 1-SPD. Sci Rep 7:3809. https:// doi.org/10.1038/s41598-017-03680-2

73. Tardito D, Tura GB, Bocchio L et al (2000) Abnormal levels of cAMP-dependent protein kinase regulatory subunits in platelets from schizophrenic patients. Neuropsychopharmacology 23:216-219. https://doi.org/10.1016/S0893-133X(99)00161-X

74. Anderson ME, Brown JH, Bers DM (2012) CaMKII in myocardial hypertrophy and heart failure. J Mol Cell Cardiol 51:468473. https://doi.org/10.1016/j.yjmcc.2011.01.012.CaMKII

75. Layland JJ, Liew D, Prior DL (2009) Clozapine-induced cardiotoxicity: a clinical update. Med J Aust 190:190-192. https:// doi.org/10.5694/j.1326-5377.2009.tb02345.x

76. Knoph KN, Morgan RJ, Palmer BA et al (2018) Clozapineinduced cardiomyopathy and myocarditis monitoring: a systematic review. Schizophr Res 199:17-30. https://doi.org/10. 1016/j.schres.2018.03.006

77. Emamian ES (2012) AKT/GSK3 signaling pathway and schizophrenia. Front Mol Neurosci 5:33. https://doi.org/10.3389/ fnmol.2012.00033

78. English JA, Fan Y, Föcking M et al (2015) Reduced protein synthesis in schizophrenia patient-derived olfactory cells. Transl Psychiatry 5:e663. https://doi.org/10.1038/tp.2015.119

79. Topol A, English JA, Flaherty E et al (2015) Increased abundance of translation machinery in stem cell-derived neural progenitor cells from four schizophrenia patients. Transl Psychiatry 5:e662. https://doi.org/10.1038/tp.2015.118

80. Chen YC, Chang YW, Huang YS (2019) Dysregulated translation in neurodevelopmental disorders: an overview of autismrisk genes involved in translation. Dev Neurobiol 79:60-74. https://doi.org/10.1002/dneu.22653

81. Amorim IS, Lach G, Gkogkas CG (2018) The role of the eukaryotic translation initiation factor 4E (eIF4E) in neuropsychiatric disorders. Front Genet 9:561. https://doi.org/10.3389/fgene. 2018.00561

82. Umegaki Y, Brotons AM, Nakanishi Y et al (2018) Palladin is a neuron-specific translational target of mTOR signaling that regulates axon morphogenesis. J Neurosci 38:4985-4995. https://doi.org/10.1523/JNEUROSCI.2370-17.2018

83. Bowling H, Zhang G, Bhattacharya A et al (2014) Antipsychotics activate mTORC1-dependent translation to enhance neuronal morphological complexity. Sci Signal 7:ra4. https:// doi.org/10.1126/scisignal.2004331

84. English JA, Pennington K, Dunn MJ, Cotter DR (2011) The neuroproteomics of schizophrenia. Biol Psychiatry 69:163172. https://doi.org/10.1016/j.biopsych.2010.06.031
85. Mistry M, Gillis J, Pavlidis P (2013) Genome-wide expression profiling of schizophrenia using a large combined cohort. Mol Psychiatry 18:215-225. https://doi.org/10.1038/mp.2011.172

86. Vachev TI, Todorov Popov N, Krasteva Stoyanova V et al (2016) Down regulation of MIR-320 gene family members in the peripheral blood of schizophrenia patients. Int J Curr Microbiol Appl Sci 5:221-230. https://doi.org/10.20546/ijcmas.2016.501.020

87. Duarte RRR, Bachtel ND, Côtel M-C et al (2018) Psychiatric risk gene NT5C2 regulates protein translation in human neural progenitor cells. bioRxiv. https://doi.org/10.1101/468546

88. Kim MK, Kim SH, Yu HS et al (2012) The effect of clozapine on the AMPK-ACC-CPT1 pathway in the rat frontal cortex. Int J Neuropsychopharmacol 15:907-917. https://doi.org/10.1017/ S1461145711000976

89. Martins-de-Souza D, Lebar M, Turck CW (2011) Proteome analyses of cultured astrocytes treated with MK-801 and clozapine: similarities with schizophrenia. Eur Arch Psychiatry Clin Neurosci 261:217-228. https://doi.org/10.1007/ s00406-010-0166-2

90. Seabra G, de Almeida V, Reis-de-Oliveira G et al (2020) Ubiquitin-proteasome system, lipid metabolism and DNA damage repair are triggered by antipsychotic medication in human oligodendrocytes: implications in schizophrenia. Sci Rep 10:1-15. https://doi.org/10.1038/s41598-020-69543-5

91. Sekino Y, Kojima N, Shirao T (2007) Role of actin cytoskeleton in dendritic spine morphogenesis. Neurochem Int 51:92104. https://doi.org/10.1016/j.neuint.2007.04.029

92. Hasan A, Nitsche MA, Rein B et al (2011) Dysfunctional longterm potentiation-like plasticity in schizophrenia revealed by transcranial direct current stimulation. Behav Brain Res 224:15-22. https://doi.org/10.1016/j.bbr.2011.05.017

93. Hasan A, Nitsche MA, Herrmann M et al (2012) Impaired long-term depression in schizophrenia: a cathodal tDCS pilot study. Brain Stimul 5:475-483. https://doi.org/10.1016/j.brs. 2011.08.004

94. Bauer DE, Haroutunian V, McCullumsmith RE, Meador-Woodruff JH (2009) Expression of four housekeeping proteins in elderly patients with schizophrenia. J Neural Transm 116:487491. https://doi.org/10.1007/s00702-008-0143-3

95. Matthews PR, Eastwood SL, Harrison PJ (2012) Reduced myelin basic protein and actin-related gene expression in visual cortex in schizophrenia. PLoS ONE 7:e38211. https://doi.org/ 10.1371/journal.pone.0038211

96. Martins-de-Souza D, Schmitt A, Röder R et al (2010) Sexspecific proteome differences in the anterior cingulate cortex of schizophrenia. J Psychiatr Res 44:989-991. https://doi.org/ 10.1016/j.jpsychires.2010.03.003

97. Ellenbroek B, Cesura A (2015) Antipsychotics and the dopamine-serotonin connection. In: Celanire S, Poli S (eds) Small molecule therapeutics for schizophrenia SE-51. Springer International Publishing, Cham, pp 1-49

98. English JA, Dicker P, Föcking M et al (2009) 2-D DIGE analysis implicates cytoskeletal abnormalities in psychiatric disease. Proteomics 9:3368-3382. https://doi.org/10.1002/pmic.20090 0015

99. Hall J, Trent S, Thomas KL et al (2015) Genetic risk for schizophrenia: convergence on synaptic pathways involved in plasticity. Biol Psychiatry 77:52-58. https://doi.org/10.1016/j. biopsych.2014.07.011

100. Gururajan A, Van Den Buuse M (2014) Is the mTOR-signalling cascade disrupted in schizophrenia? J Neurochem 129:377387. https://doi.org/10.1111/jnc. 12622

101. Liko D, Hall MN (2015) mTOR in health and in sickness. J Mol Med 93:1061-1073. https://doi.org/10.1007/ s00109-015-1326-7 
102. Ryskalin L, Limanaqi F, Frati A et al (2018) mTOR-related brain dysfunctions in neuropsychiatric disorders. Int J Mol Sci 19:11-13. https://doi.org/10.3390/ijms19082226

103. Pham X, Song G, Lao S et al (2016) The DPYSL2 gene connects mTOR and schizophrenia. Transl Psychiatry 6:e933e938. https://doi.org/10.1038/tp.2016.204

104. Swiech L, Perycz M, Malik A, Jaworski J (2008) Role of mTOR in physiology and pathology of the nervous system. Biochim Biophys Acta Proteins Proteomics 1784:116-132. https://doi.org/10.1016/j.bbapap.2007.08.015

105. Lee Y, Kim SG, Lee B et al (2017) Striatal transcriptome and interactome analysis of Shank3-overexpressing mice reveals the connectivity between Shank3 and mTORC1 signaling. Front Mol Neurosci 10:1-14. https://doi.org/10.3389/fnmol. 2017.00201

106. Lamming DW, Demirkan G, Boylan JM et al (2014) Hepatic signaling by the mechanistic target of rapamycin complex 2 (mTORC2). FASEB J 28:300-315. https://doi.org/10.1096/fj. 13-237743

107. Siuta MA, Robertson SD, Kocalis H et al (2010) Dysregulation of the norepinephrine transporter sustains cortical hypodopaminergia and schizophrenialike behaviors in neuronal rictor null mice. PLoS Biol 8:e1000393. https://doi.org/10.1371/ journal.pbio. 1000393

108. Sarbassov DD, Ali SM, Kim D-H et al (2004) Rictor, a novel binding partner of mTOR, defines a rapamycin-insensitive and raptor-independent pathway that regulates the cytoskeleton. Curr Biol 14:1296-1302. https://doi.org/10.1016/j.cub.2004. 06.054

109. Laplante M, Sabatini DM (2012) MTOR signaling in growth control and disease. Cell 149:274-293. https://doi.org/10. 1016/j.cell.2012.03.017

110. Carson RP, Fu C, Winzenburger P, Ess KC (2013) Deletion of rictor in neural progenitor cells reveals contributions of mTORC2 signaling to tuberous sclerosis complex. Hum Mol Genet 22:140-152. https://doi.org/10.1093/hmg/dds414

111. Costa-Mattioli M, Monteggia LM (2013) mTOR complexes in neurodevelopmental and neuropsychiatric disorders. Nat Neurosci 16:1537-1543. https://doi.org/10.1038/nn.3546
112. Mao Z, Zhang W (2018) Role of mTOR in glucose and lipid metabolism. Int J Mol Sci 19:2043. https://doi.org/10.3390/ ijms 19072043

113. Mayfield K, Siskind D, Winckel K et al (2015) Treatment of clozapine-associated obesity and diabetes with exenatide (CODEX) in adults with schizophrenia: study protocol for a pilot randomised controlled trial. BJPsych Open 1:67-73. https://doi.org/10.1192/bjpo.bp.115.001073

114. Park SW, Seo MK, McIntyre RS et al (2018) Effects of olanzapine and haloperidol on mTORC1 signaling, dendritic outgrowth, and synaptic proteins in rat primary hippocampal neurons under toxic conditions. Neurosci Lett 686:59-66. https:// doi.org/10.1016/j.neulet.2018.08.031

115. Deslauriers J, Desmarais C, Sarret P, Grignon S (2013) $\alpha$-Lipoic acid interaction with dopamine D2 receptor-dependent activation of the Akt/GSK-3 $\beta$ signaling pathway induced by antipsychotics: potential relevance for the treatment of schizophrenia. J Mol Neurosci 50:134-145. https://doi.org/10.1007/ s12031-012-9884-4

116. Kedracka-Krok S, Swiderska B, Jankowska U et al (2016) Stathmin reduction and cytoskeleton rearrangement in rat nucleus accumbens in response to clozapine and risperidone treatment-comparative proteomic study. Neuroscience 316:63-81. https://doi.org/10.1016/j.neuroscience.2015.12.028

117. Sai Y, Wu Q, Le W et al (2008) Rotenone-induced PC12 cell toxicity is caused by oxidative stress resulting from altered dopamine metabolism. Toxicol Vitr 22:1461-1468. https://doi. org/10.1016/j.tiv.2008.04.019

118. Zeng Z, Wang X, Bhardwaj SK et al (2017) The atypical antipsychotic agent, clozapine, protects against corticosteroneinduced death of PC12 cells by regulating the Akt/FoxO3a signaling pathway. Mol Neurobiol 54:3395-3406. https://doi. org/10.1007/s12035-016-9904-4

Publisher's Note Springer Nature remains neutral with regard to jurisdictional claims in published maps and institutional affiliations. 